\title{
Influence of silver nanoparticles on food components in wheat
}

\author{
A. Nawrocka* and J. Cieśla \\ Institute of Agrophysics Polish Academy of Sciences, Doświadczalna 4, 20-290 Lublin, Poland
}

Received June 18, 2010; accepted Ocober 27, 2010

\begin{abstract}
A b s t r a c t. During storage, grain might be affected by bacterial and fungal infections. Pathogens diminish the grain quality through contamination with excrements and second metabolites. It is very important to prevent grain from infections. Due to their antimicrobial properties, silver nanoparticles can play the role of an effective protector. The influence of nanoparticles on wheat quality was studied. The gluten parameters and falling number did not change after covering the grain with silver nanoparticles stabilized by sodium citrate. Changes in the structure of starch and gluten were investigated using Fourier-transform infrared spectroscopy. Infrared spectra of the whole meal and starch have shown a slight shift (from 1000 to $995 \mathrm{~cm}^{-1}$ ) of the band connected with the $\mathrm{C}-\mathrm{O}-\mathrm{H}$ bending. This displacement is probably related to the changes in sample moisture. Significant differences, corresponding to changes in the protein secondary structure, have appeared in the gluten spectra after covering. A decrease of absorbance in the amide and $\mathrm{CH}$ and $\mathrm{OH}$ regions has been observed regardless of the covering time.

$\mathrm{K}$ e y w o r d s: silver nanoparticles, wheat, gluten, falling number, FT-IR spectroscopy
\end{abstract}

\section{INTRODUCTION}

World production averages two billion of plant products annually. Crops storage/transport in proper conditions is crucial for avoiding heavy losses in yield and providing food with substantial amounts of nutrients of the highest quality. Post-harvest losses are due to bacterial and fungal infections, and insect pest infestations. The microorganisms and insect pests contaminate the stored/transport crops with metabolites and excrements. Among microbial metabolites, mycotoxins are regarded as the most dangerous.

Mycotoxins are a group of toxins structurally related to secondary metabolites produced mainly by the following fungal species: Fusarium, Aspergillus, and Penicilium (Narvankar et al., 2009). One of the research fields is seeking a fast, non-invasive, cheap, and quantitative technique of

*Corresponding author e-mail: a.nawrocka@ipan.lublin.pl mycotoxin detection in food products. The techniques include immunosensors ( $\mathrm{Li}$ et al., 2009), sensors based on nanoparticles (Khan and Dhayal, 2008; Tang et al., 2009), acoustic methods (Juodeikiene et al., 2008), and analytical methods (Binder, 2007). Other studies are connected with the process of food decontamination. The aim of this process is to reduce or eliminate toxic effects by destroying, modifying, or absorbing mycotoxin. The mycotoxin detoxification strategies are classified depending on the type of treatmentphysical, chemical, or microbiological. Unfortunately, these methods only diminish the mycotoxin level and production of conidia. Only gamma radiation can destroy the toxins (Binder, 2007).

Generally, most mycotoxins are chemically stable so they tend to survive storage and processing like cooking or cereal extrusion. Mycotoxins are notoriously difficult to remove and the best method of control is prevention. Although there are adequate regulations concerning the grain storage, food is still contaminated by pathogens and their metabolites. For this reason, an efficient protector is needed to prevent the grain and other food products eg fruits, vegetables from development of pathogenic microorganisms. Silver nanoparticles seem to be a good candidate for a protective substance due to their broad spectrum of antimicrobial properties.

Recently, silver nanoparticles (AgNPs) and their antimicrobial properties are widely studied. This is connected with their potential use in medicine to reduce infections as well as to prevent bacterial colonization of medical equipment (Maillard et al., 2002). AgNPs can also be employed as absorbent pads in food packaging to absorb moisture and fluids exuded from meat and fish, keeping the products looking fresh and creating an aesthetically attractive packaging. Although the mechanism of the action of silver nanoparticles 
on fungal and bacterial cells is not recognized precisely, different silver technologies have been approved by the Food and Drug Administration (FDA) and the European Food Safety Authority (EFSA).

The antimicrobial properties of AgNPs depend mainly on their size. Fernandez et al. (2009) studied the antimicrobial activity of silver microparticles and nanoparticles. The studies have shown that nanoparticles conferred higher antimicrobial potency in comparison with microparticles for the same silver content. This is connected with the higher surface-to-volume ratio of the AgNPs. Other researches also confirmed that smaller silver nanoparticles show remarkably better antimicrobial properties (Guzman et al., 2009).

The aim of the current study was to determine the potential influence of spherical silver nanoparticles stabilized by sodium citrate on the quality of wheat grain by measuring the following parameters: wet gluten, dry gluten, the gluten index, and the falling number. Furthermore, the effects of AgNPs on the structure of starch and gluten were studied using FT-IR spectroscopy. The wheat grain was covered with a thin layer of AgNPs, which can protect wheat grain from development of pathogenic microorganisms and accumulation of their toxic metabolites.

\section{MATERIAL AND METHODS}

The study was carried out on two winter varieties of wheat (Triticum aestivum L.): Bamberka and Fregata. The varieties studied belong to a bread category (cat. B). All the varieties were obtained from the Strzelce Plant Breeding Station, Poland. The mass, diameter, moisture content and hardness index of the varieties studied are presented in Table 1. The physical parameters were measured by the Perten Single Kernel Characterization System (SKCS 4100, Perten Instruments, Springfield, IL, USA).

Silver nitrate and trisodium citrate were purchased from Sigma-Aldrich and used as received. Double-distilled water was used.

Citrate-reduced and stabilized silver colloid was prepared according to a modified procedure reported by Lee and Meisel (1982). Briefly, $100 \mathrm{ml}$ of $1 \mathrm{mM} \mathrm{AgNO}_{3}$ was brought to boiling. A solution of $1 \%$ sodium citrate $(2 \mathrm{ml})$ was immediately added under vigorous stirring. The solution

T a b l e 1. Mean values of weight, diameter, moisture content, and hardness index measured by the SKCS system for the varieties of wheat studied

\begin{tabular}{lcc}
\hline \multirow{2}{*}{$\begin{array}{l}\text { SKCS } \\
\text { parameter }\end{array}$} & \multicolumn{2}{c}{ Wheat varieties } \\
\cline { 2 - 3 } & Bamberka (s.d.) & Fregata (s.d.) \\
\hline Weight (mg) & $52.2(9.50)$ & $41.8(7.10)$ \\
Diameter (mm) & $3.31(0.36)$ & $2.99(0.28)$ \\
Moisture (\%) & $11.10(0.44)$ & $10.50(0.42)$ \\
Hardness index & $70.7(13.50)$ & $51.7(13.10)$ \\
\hline
\end{tabular}

was kept boiling and stirred simultaneously for $c a .10-15 \mathrm{~min}$. A change of the solution colour to yellow was a sign of formation of spherical silver nanoparticles. This kind of nanoparticles was chosen due to their high antimicrobial activity (Guzman et al., 2009).

The absorption spectrum of the AgNPs obtained was recorded on a Cary 300/Biomelt spectrophotometer (Varian Pty, USA).

The size distribution of the colloidal silver nanoparticles was characterized by the use of the dynamic light scattering (DLS) method (Pecora, 2000). Measurements were performed on a ZetaSizer Nano ZS (Malvern Instruments Ltd., UK) apparatus at $20^{\circ} \mathrm{C}\left( \pm 0.1^{\circ} \mathrm{C}\right)$. The apparatus contains a $4 \mathrm{~mW}$ He-Ne laser with a wavelength $632.8 \mathrm{~nm}$ and the scattered light is detected at an angle $173^{\circ}$ (Non-Invasive Back-Scatter Technique). The refractive index $(\mathrm{RI}=0.13$; Palik, 1985) and absorbance $(\mathrm{A}=0.11$ at $\lambda=632.8 \mathrm{~nm})$ of AgNPs were used for transformation of size distribution from intensity to volume, based on the Mie theory. The appropriate parameters for water as a dispersant were defined by the apparatus software $(\mathrm{RI}=1.33$ and $\eta=1.0031 \mathrm{cP})$. The measurements were made with six repetitions by collecting not less than twelve sub-runs for each one. The particle size was determined by analysis of peak location.

$100 \mathrm{~g}$-samples of the wheat grain were covered with $30 \mathrm{ml}$ solution of AgNPs stabilized by sodium citrate. Solutions of $20,30,40$, and $50 \mathrm{ml}$ were also used in the covering process, but a few millilitres of AgNPs were not absorbed by the grain in the case of the $40-$ and $50-\mathrm{ml}$ solutions. $20 \mathrm{ml}$ of solutions were insufficient to cover the grain properly due to lack of solution excess after the covering process. For this reason, solution of $30 \mathrm{ml}$ was chosen as the most adequate. For AgNPs, three times of covering were used: 10, 20 and $30 \mathrm{~min}-\mathrm{T} 10, \mathrm{~T} 20$, and T30, respectively. The covering time below $1 \mathrm{~h}$ was chosen according to Woźniak (2004). The time longer than $1 \mathrm{~h}$ promoted endosperm cracking and facilitated microbial infections. After covering, the wheat samples were air-dried for $24 \mathrm{~h}$ at the temperature of $22^{\circ} \mathrm{C}$. Next, the covered grain was milled and used for further tests.

Wet gluten (WG), gluten index (GI), and dry gluten (DG) were measured using a Glutomatic 2200 washer (Perten Instruments, Sweden) and Glutork 2020, respectively, according to Approved Method 38-12 (AACCI, 2000).

The falling number (FN) was determined according to Approved Method 56-81B (AACCI, 2000) in 7g-samples of whole meal using the Hagberg-Perten method. A Falling Number 1900 apparatus (Perten Instruments, Sweden) was used.

Gluten and starch samples obtained from the gluten tests were freeze-dried and dried in a laboratory dryer, respectively. Next, the dried samples were used for the Fouriertransform infrared spectra (FT-IR) measurements. After drying, the moisture content (MC) of whole meal, starch, and gluten were measured using the Dry Mass Determination System (HD63 model, Mettler - Toledo, Poland). 
Fourier-transform infrared spectra of whole meal, starch, and freeze-dried gluten were recorded with a Nicolet 6700 FT-IR spectrometer (Thermo Electron Corporation, USA) with the Smart Orbit attachment with a diamond plate (attenuated total reflectance mode). The IR spectra were recorded between 4000 and $600 \mathrm{~cm}^{-1}$ at $4 \mathrm{~cm}^{-1}$ intervals. Each spectrum resulted from 128 scans which were averaged to give absorbance values as a function of wavenumber (WN) $\left(\mathrm{cm}^{-1}\right)$. For each sample, 10 spectra were recorded and averaged to obtain a better signal-to-noise ratio. The position of the characteristic peaks for whole meal, freeze-dried gluten, and starch was determined from the spectra.

The statistical analysis was carried out with STATISTICA version 10 (StatSoft Inc., USA). Univariate analysis of variance (ANOVA) was used to test the hypothesis of time-related differences in the WG, DG, GI, and FN values and the position of a few characteristic peaks in the FT-IR spectra of whole meal (1 001, 1533,1643 and $\left.3278 \mathrm{~cm}^{-1}\right)$, starch $\left(860,999\right.$ and $\left.3278 \mathrm{~cm}^{-1}\right)$, and freeze-dried gluten $\left(1235,1519,1644,3062,3200\right.$ and $\left.3276 \mathrm{~cm}^{-1}\right)$. P-values below 0.05 were considered significant.

\section{RESULTS AND DISCUSSION}

The ultraviolet-visible spectrocsopy (UV-VIS) spectrum confirms the formation of silver nanoparticles. The absorption spectrum of silver nanoparticles stabilized by sodium citrate is given in Fig. 1. It showed a surface plasmon resonance (SPR) absorption band with a maximum of $413 \mathrm{~nm}$ indicating the presence of spherical AgNPs with a diameter of $c a .20 \mathrm{~nm}$.

The AgNPs diameter has been confirmed by dynamic light scattering (DLS) measurements (Fig. 2). For the analyzed samples, the size distribution by intensity was with peak means at $1.5 \mathrm{~nm}$ (width of $0.3 \mathrm{~nm}, 4.3 \%$ of the area), $29.8 \mathrm{~nm}$ (width of $10.0 \mathrm{~nm}, 82.0 \%$ of the area), $331.4 \mathrm{~nm}$ (width of $144.3 \mathrm{~nm}, 10.8 \%$ of the area), and $4764 \mathrm{~nm}$ (width of $2348 \mathrm{~nm}$, $2.9 \%$ of the area), respectively. By conversion into volume, the peak at $331.4 \mathrm{~nm}$ disappeared, so the concentration of the aggregates was low.

The size of silver nanoparticles is very important because it is connected with their antimicrobial properties (Fernandez et al., 2009). The UV-VIS spectrum and DLS measurements confirm the formation of silver nanoparticles with a diameter of $c a$. $20 \mathrm{~nm}$ and an SPR band at $413 \mathrm{~nm}$. Citratestabilized AgNPs were studied by MacCuspie (2011) and Li et al. (2011) using UV-VIS spectroscopy and the DLS method. DLS measurements showed that the AgNPs size was $20 \mathrm{~nm}$, but the SPR band was located at $390 \mathrm{~nm}$. Similarly, the absorption peak of AgNPs was produced at $389 \mathrm{~nm}$ in the studies of Frederix et al. (2003). The size of citrate-stabilized AgNPs, verified using transmission electron microscopy (TEM), was found to be $21 \pm 9 \mathrm{~nm}$. The red-shift of the absorption band observed in the present study may be connected with the presence of two fractions of bigger particles (331.4 and $4764 \mathrm{~nm}$ ). It is a well known fact that the position

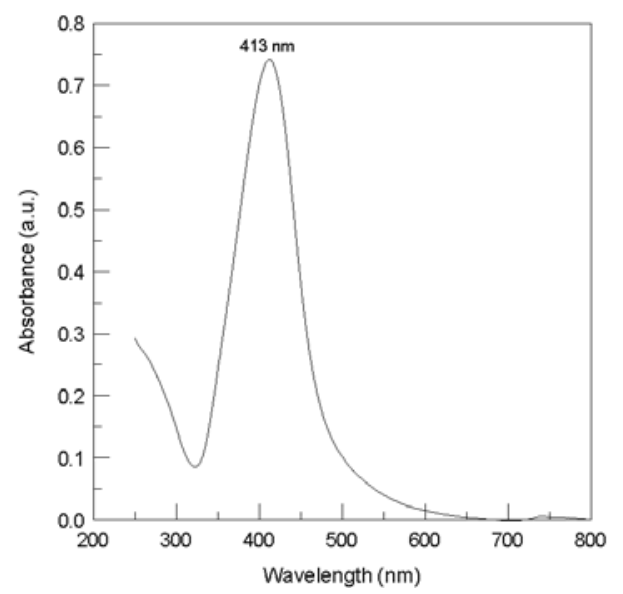

Fig. 1. Absorption spectrum of AgNPs stabilized by sodium citrate in water. Concentration of AgNPs c $=1 \mathrm{mM}$.

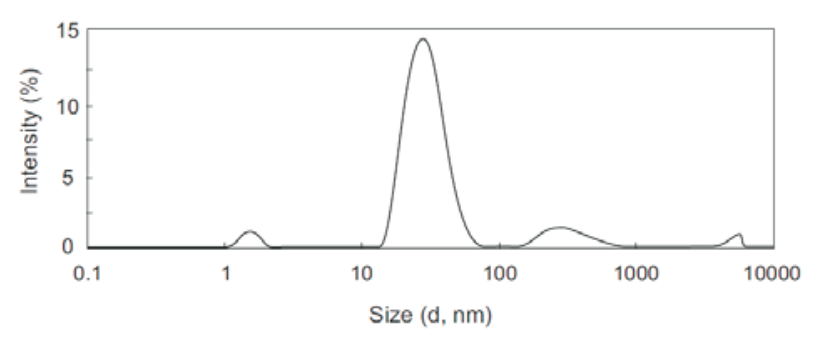

Fig. 2. Mean AgNPs size distribution by light intensity obtained from six measurements.

of the SPR absorption band depends strongly on the nanoparticle size. The absorption band is red-shifted for bigger nanoparticles (Kelly et al., 2003). It has to be noted that both MacCuspie (2011) and Frederix et al. (2003) used sodium borohydrate as a reducing agent. On the other hand, Guzman et al. (2009) studied AgNPs stabilized and reduced by sodium citrate. Their size was determined by TEM as well as UV-VIS spectroscopy. TEM photographs indicated that the particles ranged in size from 15 to $48 \mathrm{~nm}$ with the average size of about $30 \mathrm{~nm}$, while the absorption spectrum had a maximum at $412 \mathrm{~nm}$. The colloidal solution of AgNPs reduced and stabilized by sodium citrate is a mixture of nanoparticles of different size. Moreover, the nanoparticles size depends probably on the reducing agent used.

Wet gluten, dry gluten, gluten index, and the falling number are the parameters which determine the quality of wheat grain. The mean values of the parameters for the control and covered samples of the varieties studied are presented in Table 2. The correlation between the WG parameter and the covering time is significant for Bamberka $(p=0.0001)$, while wet gluten of Fregata is statistically insignificant $(p=0.08)$. Similarly, dry gluten of Bamberka $(p<0.0001)$ shows a significant correlation with the covering time, while it is insignificant for the Fregata variety $(\mathrm{p}=0.068)$. On the other hand, the activity of the $\alpha$-amylase 
T a b l e 2. Mean values of GI and FN for the wheat varieties studied (Bamberka and Fregata). Wheat was covered by sodium citrate-stabilized AgNPs

\begin{tabular}{|c|c|c|}
\hline $\begin{array}{l}\text { Covering time } \\
\quad(\min )\end{array}$ & Bamberka & Fregata \\
\hline \multicolumn{3}{|c|}{ Wet gluten (s.d.) (\%) } \\
\hline T0 & $30.2(0.1)$ & $30.1(0.4)$ \\
\hline $\mathrm{T} 10$ & $30.5(0.3)$ & $29.6(0.2)$ \\
\hline $\mathrm{T} 20$ & $30.4(0.2)$ & $30.0(0.4)$ \\
\hline $\mathrm{T} 30$ & $30.9(0.2)$ & $30.0(0.2)$ \\
\hline \multicolumn{3}{|c|}{ Dry gluten (s.d.) (\%) } \\
\hline T0 & $30.2(0.1)$ & $30.1(0.4)$ \\
\hline $\mathrm{T} 10$ & $30.5(0.3)$ & $29.6(0.2)$ \\
\hline $\mathrm{T} 20$ & $30.4(0.2)$ & $30.0(0.4)$ \\
\hline $\mathrm{T} 30$ & $30.9(0.2)$ & $30.0(0.2)$ \\
\hline \multicolumn{3}{|c|}{ Gluten index (s.d.) (\%) } \\
\hline T0 & $90.6(1.2)$ & $93.7(0.5)$ \\
\hline $\mathrm{T} 10$ & $89.0(0.7)$ & $90.6(0.4)$ \\
\hline $\mathrm{T} 20$ & $91.4(0.5)$ & $90.7(0.4)$ \\
\hline $\mathrm{T} 30$ & $92.7(0.5)$ & $90.3(0.4)$ \\
\hline \multicolumn{3}{|c|}{ Falling number (s.d.) (s) } \\
\hline T0 & $90.6(1.2)$ & $93.7(0.5)$ \\
\hline $\mathrm{T} 10$ & $89.0(0.7)$ & $90.6(0.4)$ \\
\hline $\mathrm{T} 20$ & $91.4(0.5)$ & $90.7(0.4)$ \\
\hline $\mathrm{T} 30$ & $92.7(0.5)$ & $90.3(0.4)$ \\
\hline
\end{tabular}

enzyme described by the falling number is significant for the Fregata variety $(\mathrm{p}<0.0001)$, whereas the FN values of Bamberka show no significance $(p=0.21)$. A significant correlation between the gluten index and the covering time are observed for both varieties (Bamberka $-\mathrm{p}<0.0001$ and Fregata $-\mathrm{p}<0.0001)$.

The values of wet gluten, dry gluten, and the gluten index (Table 2) indicate that the quality of wheat grain does not change after covering it with silver nanoparticles stabilized by sodium citrate. The values of GI $(89 \div 93 \%)$ indicate high strength of wet gluten, which does not diminish after applying AgNPs. The values of the falling number do not change significantly for Bamberka variety either, but the FN of Fregata decreases by $c a .100 \mathrm{~s}$. Although the parameter decreases after AgNPs covering, its value still indicates low amylase activity, which is characteristic for sound wheat (Operating Manual of Falling Number 1900).

The infrared spectra of whole meal, starch, and freezedried gluten obtained from uncovered wheat grain of the Fregata variety are presented in Fig. 3. The spectra of the other variety are similar. All the spectra show oscillations in

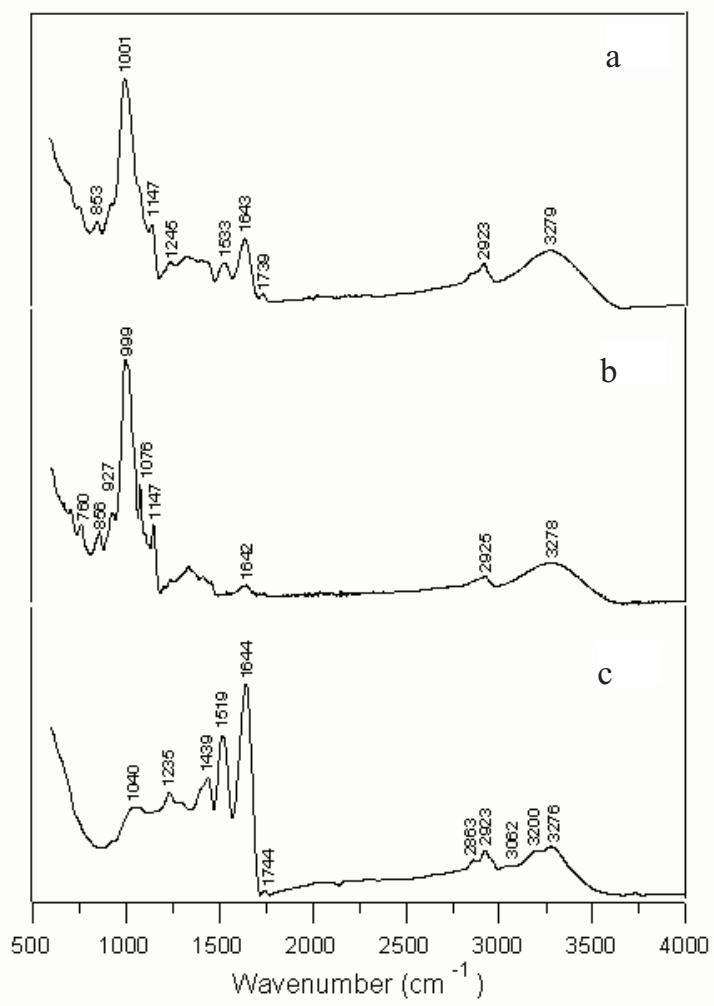

Fig. 3. FT-IR spectra of: $\mathrm{a}$ - whole meal, $\mathrm{b}$ - starch, c-freeze-dried gluten obtained from uncovered wheat.

two regions: $600-1750 \mathrm{~cm}^{-1}$ and $2900-4000 \mathrm{~cm}^{-1}$. Table 3 represents dependence of the selected bands (position and absorbance) of whole meal, starch, and gluten on the covering time.

The FT-IR spectrum of whole meal contains peaks that can be assigned to starch $\left(853,1001\right.$ and $\left.1147 \mathrm{~cm}^{-1}\right)$, proteins $\left(1245,1533\right.$ and $\left.1643 \mathrm{~cm}^{-1}\right)$, lipids $\left(1739 \mathrm{~cm}^{-1}\right)$, and water $\left(3279 \mathrm{~cm}^{-1}\right)$. The IR band centred at $3279 \mathrm{~cm}^{-1}$ is connected with the O-H stretching in water molecules (Ait Kaddour et al., 2008). However, Andreani et al. (2009), who studied FT-IR spectra of gluten powder and wheat gluten microspheres, claimed that this band resulted from an overlap of the stretching vibration of the $\mathrm{N}-\mathrm{H}$ and $\mathrm{O}-\mathrm{H}$ groups. This peak and the peak at $2923 \mathrm{~cm}^{-1}$ are present in all the spectra shown in Fig. 3. The band located at $2923 \mathrm{~cm}^{-1}$ is assigned to stretching vibrations of the $\mathrm{C}-\mathrm{H}$ group in starch and protein molecules (Irudayaraj and Yang, 2002).

The starch spectrum shows a very strong peak at $999 \mathrm{~cm}^{-1}$, which is due to $\mathrm{C}-\mathrm{O}-\mathrm{H}$ bending. Weak bands located at 760 , 856 , and $927 \mathrm{~cm}^{-1}$ are connected with the $\alpha$-configuration of the glycosidic bridge, which is typical for starch molecules (Capek et al., 2010). Absorbance at 1076 and $1147 \mathrm{~cm}^{-1}$ is also assigned to oscillations of the glycosidic bridge (Xie et al., 2006). The weak band centred at $1642 \mathrm{~cm}^{-1}$ is related to $\mathrm{C}=\mathrm{C}$ stretching (Irudayaraj and Yang, 2002). 
T a b l e 3. Mean values of moisture content (MC), wavenumber (WN) and absorbance (Abs) of selected bands for the Bamberka and Fregata varieties

\begin{tabular}{|c|c|c|c|c|c|c|c|c|c|c|}
\hline \multirow{3}{*}{ Parameters } & \multicolumn{5}{|c|}{ Bamberka } & \multicolumn{5}{|c|}{ Fregata } \\
\hline & \multicolumn{10}{|c|}{ Covering time } \\
\hline & T0 & $\mathrm{T} 10$ & $\mathrm{~T} 20$ & $\mathrm{~T} 30$ & $\mathrm{P}$ & T0 & $\mathrm{T} 10$ & $\mathrm{~T} 20$ & $\mathrm{~T} 30$ & $\mathrm{P}$ \\
\hline & \multicolumn{10}{|c|}{ Whole meal } \\
\hline $\mathrm{MC}(\%)$ & 9.56 & 8.60 & 8.35 & 8.54 & & 9.32 & 8.73 & 9.11 & 8.94 & \\
\hline $\begin{array}{l}\mathrm{WN}\left(\mathrm{cm}^{-1}\right) \\
\mathrm{Abs}\end{array}$ & $\begin{array}{c}1001 \\
0.0788\end{array}$ & $\begin{array}{c}995 \\
0.1249\end{array}$ & $\begin{array}{c}996 \\
0.956\end{array}$ & $\begin{array}{c}996 \\
0.0710\end{array}$ & $\begin{array}{c}<0.0001 \\
0.61\end{array}$ & $\begin{array}{c}1000 \\
0.0698\end{array}$ & $\begin{array}{c}995 \\
0.0720\end{array}$ & $\begin{array}{c}995 \\
0.0755\end{array}$ & $\begin{array}{c}995 \\
0.0730\end{array}$ & $\begin{array}{c}<0.0001 \\
0.56\end{array}$ \\
\hline $\begin{array}{l}\mathrm{WN}\left(\mathrm{cm}^{-1}\right) \\
\mathrm{Abs}\end{array}$ & $\begin{array}{c}1533 \\
0.0152\end{array}$ & $\begin{array}{c}1542 \\
0.0130\end{array}$ & $\begin{array}{c}1539 \\
0.0171\end{array}$ & $\begin{array}{c}1539 \\
0.0134\end{array}$ & $\begin{array}{l}<0.0001 \\
<0.0001\end{array}$ & $\begin{array}{c}1534 \\
0.0136\end{array}$ & $\begin{array}{c}1540 \\
0.0137\end{array}$ & $\begin{array}{c}1536 \\
0.0137\end{array}$ & $\begin{array}{c}1538 \\
0.0136\end{array}$ & $\begin{array}{c}<0.0001 \\
0.99\end{array}$ \\
\hline $\begin{array}{l}\mathrm{WN}\left(\mathrm{cm}^{-1}\right) \\
\mathrm{Abs}\end{array}$ & $\begin{array}{c}1643 \\
0.0231\end{array}$ & $\begin{array}{c}1646 \\
0.0510\end{array}$ & $\begin{array}{c}1646 \\
0.0264\end{array}$ & $\begin{array}{c}1646 \\
0.0202\end{array}$ & $\begin{array}{c}<0.0001 \\
0.19\end{array}$ & $\begin{array}{c}1643 \\
0.0209\end{array}$ & $\begin{array}{c}1643 \\
0.0207\end{array}$ & $\begin{array}{c}1644 \\
0.0212\end{array}$ & $\begin{array}{c}1645 \\
0.0205\end{array}$ & $\begin{array}{l}0.03 \\
0.96\end{array}$ \\
\hline $\begin{array}{l}\mathrm{WN}\left(\mathrm{cm}^{-1}\right) \\
\mathrm{Abs}\end{array}$ & $\begin{array}{c}3278 \\
0.0206\end{array}$ & $\begin{array}{c}3279 \\
0.0159\end{array}$ & $\begin{array}{c}3279 \\
0.0211\end{array}$ & $\begin{array}{c}3280 \\
0.0179\end{array}$ & $\begin{array}{c}0.02 \\
0.0002\end{array}$ & $\begin{array}{c}3279 \\
0.0175\end{array}$ & $\begin{array}{c}3280 \\
0.0184\end{array}$ & $\begin{array}{c}3279 \\
0.0189\end{array}$ & $\begin{array}{c}3279 \\
0.0184\end{array}$ & $\begin{array}{l}0.59 \\
0.68\end{array}$ \\
\hline Abs & \multicolumn{10}{|c|}{ Starch } \\
\hline $\mathrm{MC}(\%)$ & 5.41 & 7.12 & 7.52 & 8.84 & & 7.06 & 8.37 & 7.13 & 8.86 & \\
\hline $\begin{array}{l}\mathrm{WN}\left(\mathrm{cm}^{-1}\right) \\
\mathrm{Abs}\end{array}$ & $\begin{array}{c}860 \\
0.0395\end{array}$ & $\begin{array}{c}859 \\
0.0437\end{array}$ & $\begin{array}{c}859 \\
0.0443\end{array}$ & $\begin{array}{c}859 \\
0.0472\end{array}$ & $\begin{aligned} & 0.18 \\
< & 0.0001\end{aligned}$ & $\begin{array}{c}862 \\
0.0417\end{array}$ & $\begin{array}{c}860 \\
0.0819\end{array}$ & $\begin{array}{c}859 \\
0.0411\end{array}$ & $\begin{array}{c}859 \\
0.0459\end{array}$ & $\begin{array}{c}<0.0001 \\
0.37\end{array}$ \\
\hline $\begin{array}{l}\mathrm{WN}\left(\mathrm{cm}^{-1}\right) \\
\mathrm{Abs}\end{array}$ & $\begin{array}{c}999 \\
0.1231\end{array}$ & $\begin{array}{c}998 \\
0.1526\end{array}$ & $\begin{array}{c}998 \\
0.1570\end{array}$ & $\begin{array}{c}998 \\
0.1690\end{array}$ & $\begin{array}{c}0.39 \\
0.0006\end{array}$ & $\begin{array}{c}1000 \\
0.1410\end{array}$ & $\begin{array}{c}998 \\
0.1598\end{array}$ & $\begin{array}{c}997 \\
0.1422\end{array}$ & $\begin{array}{c}998 \\
0.1673\end{array}$ & $\begin{array}{l}<0.0001 \\
<0.0001\end{array}$ \\
\hline $\begin{array}{l}\mathrm{WN}\left(\mathrm{cm}^{-1}\right) \\
\mathrm{Abs}\end{array}$ & $\begin{array}{c}3278 \\
0.0201\end{array}$ & $\begin{array}{c}3275 \\
0.0255\end{array}$ & $\begin{array}{c}3276 \\
0.0261\end{array}$ & $\begin{array}{c}3276 \\
0.0287\end{array}$ & $\begin{aligned} & 0.10 \\
< & 0.0001\end{aligned}$ & $\begin{array}{c}3279 \\
0.0235\end{array}$ & $\begin{array}{c}3274 \\
0.0282\end{array}$ & $\begin{array}{c}3277 \\
0.0239\end{array}$ & $\begin{array}{c}3275 \\
0.0284\end{array}$ & $\begin{array}{c}0.01 \\
<0.0001\end{array}$ \\
\hline Abs & \multicolumn{10}{|c|}{ Freeze-dried gluten } \\
\hline $\mathrm{MC}(\%)$ & 2.23 & 2.47 & 2.57 & 4.71 & & 2.77 & 4.72 & 5.00 & 4.63 & \\
\hline $\begin{array}{l}\mathrm{WN}\left(\mathrm{cm}^{-1}\right) \\
\mathrm{Abs}\end{array}$ & $\begin{array}{c}1235 \\
0.0271\end{array}$ & $\begin{array}{c}1234 \\
0.0207\end{array}$ & $\begin{array}{c}1234 \\
0.0211\end{array}$ & $\begin{array}{c}1235 \\
0.0231\end{array}$ & $\begin{array}{c}0.009 \\
<0.0001\end{array}$ & $\begin{array}{c}1234 \\
0.0286\end{array}$ & $\begin{array}{c}1235 \\
0.0225\end{array}$ & $\begin{array}{c}1234 \\
0.0211\end{array}$ & $\begin{array}{c}1235 \\
0.0223\end{array}$ & $\begin{aligned} & 0.25 \\
< & 0.0001\end{aligned}$ \\
\hline $\begin{array}{l}\mathrm{WN}\left(\mathrm{cm}^{-1}\right) \\
\mathrm{Abs}\end{array}$ & $\begin{array}{c}1519 \\
0.0424\end{array}$ & $\begin{array}{c}1519 \\
0.0319\end{array}$ & $\begin{array}{c}1519 \\
0.0325\end{array}$ & $\begin{array}{c}1520 \\
0.0351\end{array}$ & $\begin{aligned} & 0.03 \\
< & 0.0001\end{aligned}$ & $\begin{array}{c}1519 \\
0.0444\end{array}$ & $\begin{array}{c}1519 \\
0.0339\end{array}$ & $\begin{array}{c}1521 \\
0.0323\end{array}$ & $\begin{array}{c}1519 \\
0.0342\end{array}$ & $\begin{aligned} & 0.06 \\
< & 0.0001\end{aligned}$ \\
\hline $\begin{array}{l}\mathrm{WN}\left(\mathrm{cm}^{-1}\right) \\
\mathrm{Abs}\end{array}$ & $\begin{array}{c}1644 \\
0.0567\end{array}$ & $\begin{array}{c}1644 \\
0.0415\end{array}$ & $\begin{array}{c}1643 \\
0.0427\end{array}$ & $\begin{array}{c}1642 \\
0.0455\end{array}$ & $\begin{array}{l}<0.0001 \\
<0.0001\end{array}$ & $\begin{array}{c}1645 \\
0.0587\end{array}$ & $\begin{array}{c}1641 \\
0.0437\end{array}$ & $\begin{array}{c}1642 \\
0.0414\end{array}$ & $\begin{array}{c}1643 \\
0.0443\end{array}$ & $\begin{array}{l}<0.0001 \\
<0.0001\end{array}$ \\
\hline $\begin{array}{l}\mathrm{WN}\left(\mathrm{cm}^{-1}\right) \\
\mathrm{Abs}\end{array}$ & $\begin{array}{c}3062 \\
0.0082\end{array}$ & $\begin{array}{c}3062 \\
0.0060\end{array}$ & $\begin{array}{c}3065 \\
0.0062\end{array}$ & $\begin{array}{c}3065 \\
0.0077\end{array}$ & $\begin{array}{c}0.250 \\
0.0004\end{array}$ & $\begin{array}{c}3060 \\
0.0084\end{array}$ & $\begin{array}{c}3064 \\
0.0075\end{array}$ & $\begin{array}{c}3062 \\
0.0073\end{array}$ & $\begin{array}{c}3065 \\
0.0071\end{array}$ & $\begin{array}{l}0.01 \\
0.03\end{array}$ \\
\hline $\begin{array}{l}\mathrm{WN}\left(\mathrm{cm}^{-1}\right) \\
\mathrm{Abs}\end{array}$ & $\begin{array}{c}3200 \\
0.0120\end{array}$ & $\begin{array}{c}3202 \\
0.0088\end{array}$ & $\begin{array}{c}3202 \\
0.0092\end{array}$ & $\begin{array}{c}3210 \\
0.0114\end{array}$ & $\begin{array}{c}<0.0001 \\
0.0003\end{array}$ & $\begin{array}{c}3198 \\
0.0123\end{array}$ & $\begin{array}{c}3204 \\
0.0109\end{array}$ & $\begin{array}{c}3205 \\
0.0108\end{array}$ & $\begin{array}{c}3201 \\
0.0103\end{array}$ & $\begin{array}{c}0.0003 \\
0.03\end{array}$ \\
\hline $\begin{array}{l}\mathrm{WN}\left(\mathrm{cm}^{-1}\right) \\
\mathrm{Abs}\end{array}$ & $\begin{array}{c}3276 \\
0.0132\end{array}$ & $\begin{array}{c}3279 \\
0.0099\end{array}$ & $\begin{array}{c}3277 \\
0.0103\end{array}$ & $\begin{array}{c}3277 \\
0.0126\end{array}$ & $\begin{array}{c}0.004 \\
0.0006\end{array}$ & $\begin{array}{c}3278 \\
0.0135\end{array}$ & $\begin{array}{c}3278 \\
0.0121\end{array}$ & $\begin{array}{c}3278 \\
0.0119\end{array}$ & $\begin{array}{c}3279 \\
0.0113\end{array}$ & $\begin{array}{l}0.32 \\
0.04\end{array}$ \\
\hline
\end{tabular}

The IR spectrum of freeze-dried gluten shows characteristic bands at 1644,1519 , and $1235 \mathrm{~cm}^{-1}$, related to the band frequency of amide I, amide II and amide III, respectively. The amide I band results from $\mathrm{C}=\mathrm{O}$ stretching and $\mathrm{C}-\mathrm{N}$ and $\mathrm{N}-\mathrm{H}$ stretching. Band frequency of amide II is connected with the $\mathrm{N}-\mathrm{H}$ bending and $\mathrm{C}-\mathrm{N}$ stretching, whereas $\mathrm{N}-\mathrm{H}$ bending and $\mathrm{C}-\mathrm{H}$ stretching compose the amide III band. Amide I and II bands are considered for the study of modifications in the secondary protein structure (Ait Kaddour et al., 2008). The band at $1439 \mathrm{~cm}^{-1}$ is located in the region of $\mathrm{C}-\mathrm{H}$ bending modes (Carbonaro and Nucara,
2010). This spectrum contains also a weak peak located at $1744 \mathrm{~cm}^{-1}$, which is connected with oscillations of lipid functional groups. This band is present in the spectrum, as compounds soluble in water have only been removed during gluten washing.

In the whole meal spectrum, the most noticeable is the shift to shorter wavenumbers of a band centred at $1000 \mathrm{~cm}^{-1}$ $(p<0.0001)$ after the covering process. Changes in the same band are also observed in the starch spectrum. This band is very sensitive to the water content and these vibrations involve water - starch interactions (Varatharyan et al., 2010). 

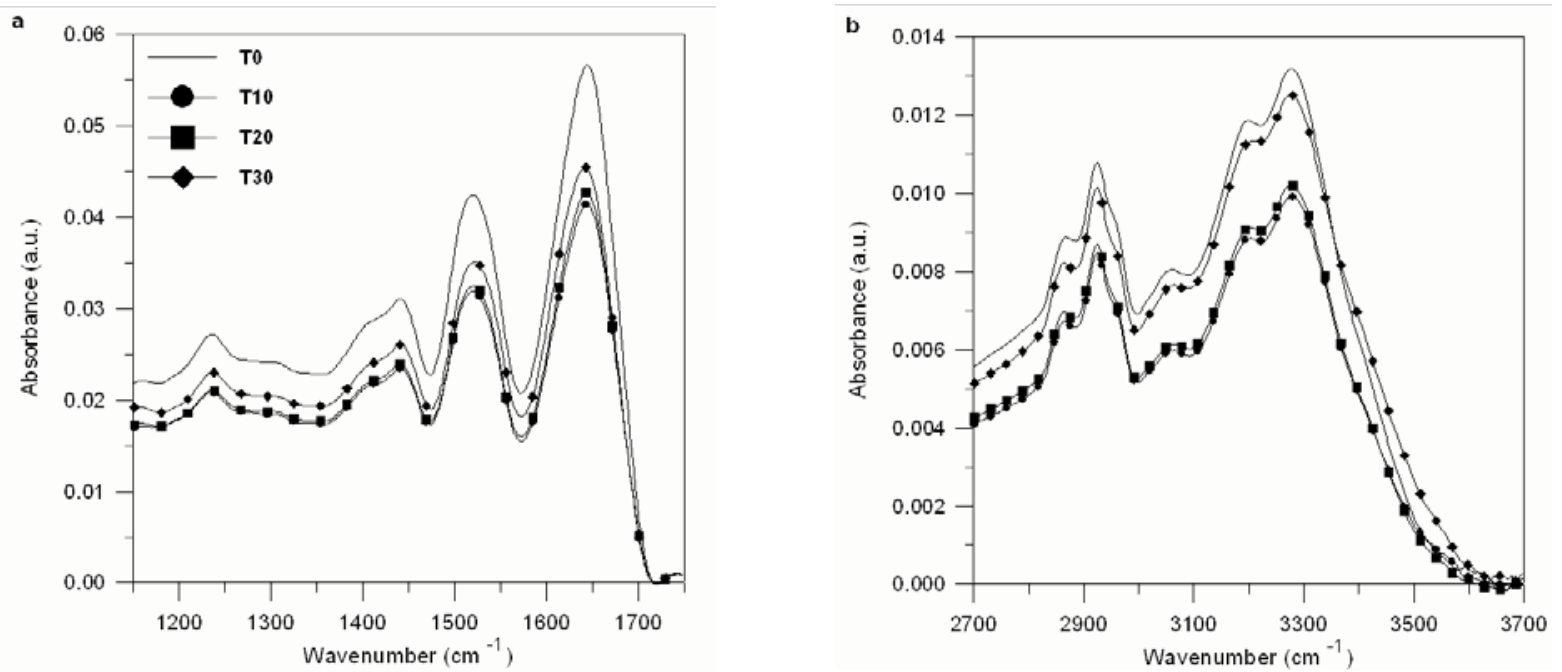

Fig. 4. FT-IR spectrum of: $\mathrm{a}-$ amides, $\mathrm{b}-\mathrm{CH}$ and $\mathrm{OH}$ region for the Bamberka variety.
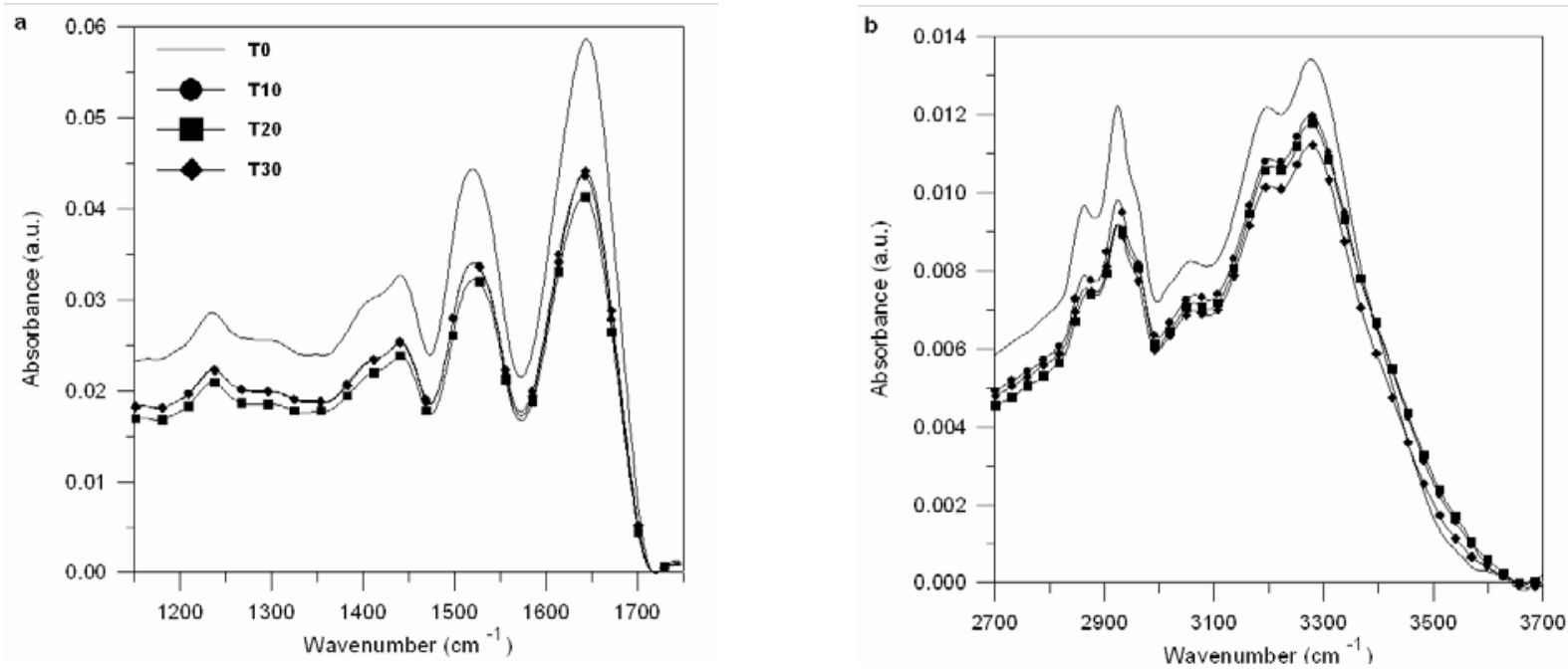

Fig. 5. FT-IR spectrum of: $\mathrm{a}$ - amides, $\mathrm{b}-\mathrm{CH}$ and $\mathrm{OH}$ region for the Fregata variety.

For this reason, the peak absorbance increases, and its maximum shifts with the increasing moisture content of the sample studied. Similarly, differences in absorbance and/or the peak position are observed for the band located at $3278 \mathrm{~cm}^{-1}$. As mentioned above, this band is connected with oscillation in water molecules and thus can change with the moisture content. The FT-IR spectra of starch and whole meal obtained from wheat grain covered by AgNPs do not show any new bands in comparison with the spectra of control samples indicating interactions between starch functional groups and silver nanoparticles or sodium citrate molecules. Xie et al. (2006) studied FT-IR spectra of starch citrates that exhibited a new band at $1724 \mathrm{~cm}^{-1}$. The band can be attributed to the ester group from citric acid.

However, the most important are changes in the gluten spectrum due to its role in the bread dough mixing. Changes in the structure of gluten were investigated by analysis of the position and absorbance of amide I, II and III bands (1 150$\left.1750 \mathrm{~cm}^{-1}\right)$ and bands from the $\mathrm{OH}$ region $\left(2700-3700 \mathrm{~cm}^{-1}\right)$. The IR spectra of these regions are presented in Figs 4 and 5 for the Bamberka and Fregata variety, respectively. The covering process, regardless of its length, causes significant changes in band intensity in both regions. Only absorbance (Abs) of the $\mathrm{OH}$ region in the $\mathrm{T} 30$ spectrum of the Bamberka va- riety is higher in comparison with the T10 and T20 spectra. Its intensity is similar to the intensity of the control sample (T0). This can be connected with the higher value of sample moisture (Table 3). Probably, for the same reason, a shift of the band at $3200 \mathrm{~cm}^{-1}$ is observed ( 3200 to $3210 \mathrm{~cm}^{-1}$ ). Although the statistical analysis has shown a significant correlation between the position of the band and the covering time, the change in wavenumber of $2-3 \mathrm{~cm}^{-1}$ is insignificant in spectroscopy. Mejri et al. (2005) studied solubility of 
wheat gluten in the presence of additives by FT-IR spectroscopy. Analysis of spectra reveals a decrease in the intensity of the whole amide region. Thus, it can be assumed that important changes in the secondary structure have occurred as a result of the effects of additives on the protein. Furthermore, changes in the band shape in the $\mathrm{OH}$ region were also observed. Changes in both regions were also observed after formation of gluten microspheres (Andreani et al., 2009). There was a shift to a shorter wavenumber in the $\mathrm{OH}$ region ( 3300 to $3286 \mathrm{~cm}^{-1}$ ) in the microsphere spectrum due to formation of hydrogen bonds between gluten molecules. No displacement was observed in the amide I band, but the amide II band was shifted to a shorter wavenumber.

\section{CONCLUSIONS}

1. Covering of wheat grain by silver nanoparticles stabilized by sodium citrate does not change its qualitative parameters (wet gluten, dry gluten, gluten index, and falling number).

2. FT-IR spectroscopy indicates a decrease in band absorbance of the amide and $\mathrm{OH}$ region. This decrease suggests that the covering process can affect the secondary structure of gluten.

3. Further research should be carried out to elucidate the nature of the changes and their cause (influence of the solvent and/or free stabilizer).

\section{REFERENCES}

Ait Kaddour A., Mondet M., and Cuq B., 2008. Application of two-dimensional cross-correlation spectroscopy to analyse infrared (MIR and NIR) spectra recorded during bread dough mixing. J. Cereal Sci., 48, 678-685.

American Association of Cereal Chemists International, 2000. Approved Methods of the AACC, The Association, St. Paul, MN, USA.

Andreani L., Cercena R., Ramos B.G.Z., and Soldi V., 2009. Development and characterization of wheat gluten microspheres for use in a controlled rease system. Mat. Sci. Eng., C 29, 524-531.

Binder E.M., 2007. Managing the risk of mycotoxins in modern feed production. Animal Feed Sci. Technol., 133, 149-166.

Capek P., Drabik M., and Turjan J., 2010. Characterization of starch and its mono and hybrid derivatives by thermal analysis and FT-IR spectroscopy. J. Thermal Analysis Calorimetry, 99, 667-673.

Carbonaro M. and Nucara A., 2010. Secondary structure of food proteins by Fourier transform spectroscopy in the midinfrared region. Amino Acids, 38, 679-690.

Fernandez A., Soriano E., Lopez-Carballo G., Picouet P., Lloret E., Gavara R., and Hernandez-Munoz P., 2009. Preservation of aseptic conditions in absorbent pads by using silver nanotechnology. Food Res. Int., 42, 1105-1112.

Frederix F., Friedt J.-M., Choi K.H., Laureyn W., Campitelli A., Mondelaers D., Maes G., and Borghs G., 2003. Biosensing based on light absorption of nanoscaled gold and silver nanoparticles. Analytical Chem., 75, 6894-6900.

Guzman M.G., Dille J., and Godet S., 2009. Synthesis of silver nanoparticles by chemical reduction method and their antibacterial activity. International J. Chem. Biol. Eng., 2(3), 104-111.

Irudayaraj J. and Yang H., 2002. Depth profiling of a heterogeneous food-packaging model using step-scan Fourier transform infrared photoacoustic spectroscopy. J. Food Eng., 55, 25-33.

Juodeikiene G., Basinskiene L., Vidmantiene D., Bartkiene E., Kunigelis V., and de Koe W.J., 2008. Rapid acoustic screening of deoxynivalenol (DON) in grain. World Mycotoxin J., $1,267-274$.

Kelly K.L., Coronado E., Zhao L.L., and Schatz G.C., 2003. The optical properties of metal nanoparticles: The influence of size, shape and dielectric environment. J. Physical Chem., B 107, 668-677.

Khan R. and Dhayal M., 2008. Nanocrystalline bioactive $\mathrm{TiO}_{2-}$ chitosan impedimetric immunosensor for ochratoxin A. Electrochem. Commun., 10, 492-495.

Lee P.C. and Meisel D., 1982. Adsorption and surface-enhanced Raman of dyes on silver and gold sols. J. Physical Chem., 86, 3391-3395.

Li P., Zhang Q., and Zhang W., 2009. Immunoassays for aflatoxins. Trends Analytical Chem., 28, 1115-1126.

Li X., Zhang M., Duan X., and Mujumdar A.S., 2011. Effect of nano-silver coating on microbial control of microwavefreeze combined dried sea cucumber. Int. Agrophys., 25, 181-186.

MacCuspie R.I., 2011. Colloidal stability of silver nanoparticles in biologically relevant conditions. J. Nanoparticle Res., 13, 2893-2908.

Maillard M., Giorgio S., and Pileni M.-P., 2002. Silver nanodisks. Advanced Mat., 14, 1084-1086.

Mejri M., Roge B., BenSouissi A., Michels F., and Mathhlouti M., 2005. Effects of some additives on wheat gluten solubility: A structural approach. Food Chem., 92, 7-15.

Narvankar D.S., Singh C.B., Jayas D.S., and White N.D.G., 2009. Assessment of soft X-ray imaging for detection of fungal infection in wheat. Biosys. Eng., 103, 49-56.

Palik E.D., 1985. Handbook of Optical Constants of Solids. Academic Press, Boston, MA, USA.

Pecora R., 2000. Dynamic light scattering measurement of nanometer particles in liquids. J. Nanoparticle Res., 2, 123-131.

Tang D., Sanceda J.C., Lin Z., Ott S., Basova E., Goryacheva I., Biselli S., Lin J., Niessner R., and Knopp D., 2009. Magnetic nanogold microspheres-based lateral-flow immunodipstick for rapid detection of aflatoxin $\mathrm{B}_{2}$ in food. Biosensors Bioelectronics, 25, 514-518.

Varatharajan V., Hoover R., Liu Q., and Seetharama K., 2010. The impact of heat-moisture treatment on the molecular structure and physicochemical properties of normal and waxy potato starches. Carbohydrate Polymers, 81, 466-475.

Woźniak W., 2004. Physical results of barley grain moisture treatment (in Polish). Acta Agrophysica, 110, 235-242 .

Xie X., Liu Q., and Ciu S.W., 2006. Studies of the granular structure of resistant starches (type 4) from normal, high amylose and waxy corn starch citrates. Food Res. Int., 39, 332-341. 